Clara Royen

\title{
Badania nad Szoa na Węgrzech (2007 - marzec 2010)
}

\section{Kierunki i stan instytucjonalny węgierskich studiów nad Zagładą}

W roku 2002 powstało w Budapeszcie Centrum Dokumentacji i Pamięci Holokaustu (Holocaust Dokumentációs Központ és Emlékgyújtemény Közalapítvány HDKE), które udostępnia bogate archiwa i zbiory oraz liczącą ponad 3500 woluminów bibliotekę na temat Zagłady oraz życia Żydów na Węgrzech i na świecie ${ }^{1}$. Stawiając sobie za cel badanie i popularyzację historii Szoa na Węgrzech, skupia grupę historyków i muzealników, którymi kieruje Szabolcs Szita, specjalizujący się w temacie przymusowej pracy Żydów na Węgrzech. Od roku 2007 Centrum publikuje materiały z seminariów i konferencji, a także księgi pamiątkowe z uroczystości organizowanych wraz z innymi ośrodkami badawczymi w Europie (jak Institut für Geschichte der Juden in Österreich). Na specjalną wzmiankę zasługuje zwłaszcza tom wydany w roku 2007, poświęcony warunkom powrotu deportowanych Żydów na Węgry, z artykułem Szity, który podaje niepublikowane dotychczas dane na temat chronologii transportów i oddźwięku, z jakim spotkały się one w prasie ${ }^{2}$. Inny tom, wskazujący nowe kierunki badań, koncentruje się na osobie Raoula Wallenberga, szczególnie ważnej dla świadomości węgierskiej. Odsłonięcie jego pomnika w 1987 r. zapoczątkowało oficjalne ożywienie pamięci Szoa w polityce. Zaproponowano ponowne przypomnienie działań Wallenberga w kontekście historycznych i społecznych uwarunkowań, które umożliwiły jego akcję ratowania Żydów w Budapeszcie To z kolei oznaczało rezygnację z kultu bohatera na rzecz szerzej pojętej historii społecznej ${ }^{3}$. W roku 2008 opublikowano materiały ze zorganizowanej w ra-

\footnotetext{
${ }^{1}$ http://www.hdke.hu/.

${ }^{2}$ Sz. Szita, A deportáltak Visszatérése és a közvélemeny 1945-1946 [Powrót deportowanych a opinia publiczna, 1945-1946], s. 43-63 [w:] J. Botos, T. Kovács, Visszatérés, újrakedezdés. Tudományos emlékülés 2006, november 23 [Powrót, nowy początek. Dzień pamięci, 23 listopada 2006], Budapest 2007.

${ }^{3}$ Üldöztetés, embermentés, újrakezdés: tudományos emlékülések 2007 április 12. és május 8. [Prześladowania, ratunek, nowy początek - konferencja 12 IV i 8 V 2007], red. J. Botos, T. Kovács, Budapest 2007.
} 
mach unijnego programu „Active European Remembrance”, austriacko-węgierskiej konferencji na temat Balf, największego obozu w prowincji Sopron, w którym robotników przymusowych wykorzystywano do budowy Südostwall ${ }^{4}$. Teksty te - choć trudno je znaleźć w księgarniach - świadczą o pewnym dynamizmie HDKE.

Badań nad Zagładą podjęły się wydziały i instytuty studiów żydowskich, a także naukowcy związani z innymi instytucjami na Węgrzech i za granicą (uniwersytety w Szegedzie i Budapeszcie, Central European University, Yad Vashem itd.). Artykuły poświęcone Szoa publikują dwa najpoważniejsze periodyki żydowskie na Węgrzech: kwartalnik „Múlt és Jövő” („Przeszłość i Przyszłość”), założony w roku 1988 przez pisarza Jánosa Kőbányai, oraz istniejący od roku 1989 tygodnik „Szombat” („Sobota”), skupiający się raczej na aktualnościach, redagowany przez pisarza Gábora T. Szántó przy współpracy wybitnych znawców tej tematyki ${ }^{5}$. Warto zaznaczyć, że w każdym numerze „Múlt és Jövő” ukazuje się rubryka „Figyelő” („Obserwator”), w której recenzowane są artykuły prasowe, spotkania, książki i konferencje dotyczące życia i Zagłady Żydów, stanowi zatem dobrą bazę danych bibliograficznych.

\section{Geografia Szoa}

Wprawdzie węgierskie badania skupiają się głównie na Zagładzie na Węgrzech, jednak sama historia nie ogranicza się do dzisiejszego terytorium państwa - na skutek przesunięć granic w latach 1938-1941 Węgry zyskały część obszaru, którego pozbawił je traktat w Trianon, zatem obecne analizy obejmują również rejony pozostające poza granicami (zwłaszcza część Słowacji, Rumunii i północną Transylwanię). Największe osiągnięcia ostatnich lat stały się możliwe dzięki współpracy amerykańskiego specjalisty Randolpha L. Brahama, pioniera badań dziejów Szoa na Węgrzech, i 22 badaczy z Węgier, Izraela, Rumunii i Stanów Zjednoczonych. Dzięki tej kooperacji w 2007 r. opublikowano trzy tomy „Encyklopedii geograficznej Holokaustu na Węgrzech”6. Ożywiając pamięć o nieistniejących gminach żydowskich encyklopedia ujmuje w porządku alfabetycznym wszystkie struktury wspólnotowe w granicach Węgier w roku 1941, kiedy to nastąpił ich kres. Każda ze wspólnot przedstawiona jest na mapce, na której zaznaczono gminy, getta i trasę deportacji. Dzięki systemowi odsyłaczy historia życia Żydów i ich zagłady została szczegółowo i przejrzyście opisana. Opracowanie zawiera liczne tablice i zdjęcia. W 2008 r. pojawił się czwarty, stanowiący obszerną bazę danych

${ }^{4}$ Aktív európai emlékezet. I. balfi nemzetközi konferencia, 2008 május 23-25 [Aktywna pamięć europejska. I kolokwium międzynarodowe o Balf, 23-25 V 2008], red. Sz. Szita, Budapest 2008.

${ }^{5}$ Por. strony internetowe dostępne także po angielsku: http://WWW.multesjovo.hu/hu/ default.asp i //szombat.portalinternet.hu/index/html.

${ }^{6}$ A magyarországi holokauszt földrajzi enciklopédiája, red. R.L. Braham, Z.T. Szabó, t. 1-3, Budapest 2007. 
tom poświęcony północnej Transylwanii, oddanej Węgrom przez Niemcy i Włochy w roku $1940^{7}$.

Braham wybrał jako współprzewodniczącego badań Zoltána Tibori Szabó, który w 2007 r. wydał książkę „Strona mroku. Żydowska świadomość tożsamości w Transylwanii po Holokauście”8, w ogromnej mierze poświęconą eksterminacji Żydów w tym rejonie - kwestiom deportacji, dóbr żydowskich, różnic między regionami północnymi a południowymi pod administracją rumuńską i węgierską, ujmując rzecz na poziomie lokalnym i rodzinnym. Autor opierał się na bogatych źródłach (statystyki, prasa, pamiętniki, dokumenty instytucji żydowskich, relacje ustne) w języku węgierskim, rumuńskim, jidysz, hebrajskim. Szabó opisuje następnie stan świadomości narodowej ocalonych w okresie po wprowadzeniu dyktatury komunistycznej. „Poszukiwanie tożsamości” przez węgierskich ocalonych było tematem poruszającego artykułu Liski Márton w roku 20099 ${ }^{9}$. Obok ogromnie ważnego dzieła Szabó pojawiło się też wiele cennych artykułów na temat Szoa w Transylwanii, spośród których przywołajmy lokalne studium Attili Gidó o „Losie Żydów z Cluju w roku 1944”10.

\section{Krytyka historiografii}

W roku 2008 na łamach 3 numeru pisma „Kommentár” poświęconego węgierskim badaniom nad Zagładą doszło do ostrej polemiki z udziałem wielu cenionych historyków. Artykuły poprzedziła wspólna deklaracja wpisująca tragedię Szoa w dzieje Węgier autorstwa dwóch ludzi o odmiennych poglądach - historyka Balázsa Ablonczego, prawicowego intelektualisty i redaktora naczelnego tegoż pisma, oraz Attili Nováka, przywódcy organizacji syjonistycznej i redaktora „Szombat”11. Wydarzenie to jest ważne ze względu na polityczny aspekt węgierskich badań nad Holokaustem w kraju, gdzie - zgodnie z szacunkami - żyje niemal 100 tys. Żydów i gdzie zdarzają się niepokojące przejawy antysemityzmu i rasizmu ${ }^{12}$.

W tym samym numerze ukazał się tekst historyka niezwiązanego z tematyką Szoa, Gábora Gyáni, który ostro skrytykował węgierskie badania13 ${ }^{13}$ Podkreślił znikome uznanie, jakim są darzone za granicą, ich izolację ze względu na barierę języ-

${ }^{7}$ Az észak-erdélyi holokauszt földrajzi enciklopédiája, red. R.L. Braham, Z.T. Szabó, Budapest-Kolozsvár 2008.

${ }^{8}$ Z.T. Szabó, Árnyékos oldal. Zsidó identitástudat Erdélyben a holokauszt után, Kolozsvár 2007.

${ }^{9}$ L. Márton, Magyar-zsidó identitáskeresés 1945 után [Węgiersko-żydowskie poszukiwanie tożsamości po roku 1945], „Múltunk” 2009/I, s. 138-180.

${ }^{10}$ A. Gidó, A kolozsvári zsidóság sorsa 1944-ben, „Rubicon” 2005, nr 2-3, 121-126

${ }^{11}$ B. Ablonczy, A. Novák, Tizenkét állitás a Soáról [12 twierdzeń o Szoa], „Kommentár” 3/2008, s. 3 .

${ }^{12}$ Cytowani badacze muszą także walczyć z negacjonistyczną historiografią, której ośrodkiem jest wydawnictwo Gede. Od roku 2007 opublikowało ono ponad dziesięć kontrowersyjnych pozycji (w tym nowy przekład Mein Kampf).

${ }^{13}$ G. Gyáni, Helyünk a Holokauszt történetírásában [Nasze miejsce w historiografii Holokaustu], ibidem, s. 13-23. 
kową, intelektualny „prowincjonalizm”, skupianie się na filozofii kosztem analizy krytycznej, nieznajomość osiągnięć innych badaczy, których prace były przecież dostępne w przekładzie na węgierski - jak Christopher Browning czy Götz Aly. Gyáni był zdania, że węgierscy badacze zaniedbują refleksję nad rolą podtrzymywania pamięci i lekceważą znaczenie przekazu ustnego. Ta krytyka, choć dotyczyła tylko części środowiska, trafnie wskazywała jednak pewne niedostatki badań jeśli chodzi o powiązania historiografii węgierskiej ze światową. Obsesja na punkcie źródeł nie jest specyficzną cechą badań nad Szoa, a publikacje dokumentów, nawet bez analizy, wydają się cenne - czego przykładem może być publikacja „»Szklana wyspa«. Carl Lutz i akcje pomocy syjonistów budapeszteńskich w roku 1944” z 2008 r., opatrzona elementarnym studium wprowadzającym, ale zawierająca niepublikowane dotąd dokumenty ${ }^{14}$.

Następne numery „Kommentár” zawierają odpowiedzi badaczy. Wśród nich zwraca uwagę ostra riposta László Karsaia, profesora historii Uniwersytetu w Szegedzie, jednego z najbardziej cenionych znawców Szoa na Węgrzech, a przy tym pioniera prac historycznych na temat eksterminacji węgierskich Cyganów, który to temat jest mocnym punktem węgierskich badań od początku lat dziewięćdziesiątych. Poza atakami ad hominem, których oszczędzę polskiemu czytelnikowi, Karsai zarzucał Gyániemu ślepotę badawczą i brak doświadczenia, odrzucił „kompleks Brahama”, skorygował pewne stwierdzenia na temat węgierskich zaniedbań, zwłaszcza w zakresie przekazu ustnego oraz pamięci ${ }^{15}$. Próbując położyć kres polemice, HKDE zebrał grono jej uczestników 2 października 2008 r., jednak i wówczas nie doszli oni do porozumienia... ${ }^{16}$

Węgierskie badania w ciągu ostatnich trzech lat wskazują na rosnące zainteresowanie źródłami oral history, tak doskonale wykorzystywanymi w kwitnących na Węgrzech gender studies. Odnosząc je do lektury Pamiętników Shoah ${ }^{17}$ Louis Vasváry, badaczka kobiecych relacji o Szoa, opublikowała ostatnio doskonały artykuł na temat ocalonych węgierskich Żydówek na emigracji ${ }^{18}$. Katalin Pécsi zredago-

${ }^{14}$ Üvegsziget. Carl Lutz és a budapesti cionisták mentőakciói 1944-ben, red. G. Vámos, Budapest 2008.

${ }^{15}$ W: A magyar Holokauszt-történetírásról. Válasz Ablonczy Balázsnak, Csíki Tamásnak, Gyáni Gábornak és Novák Attilának [O historiografii Holokaustu na Węgrzech. Odpowiedź Balázsowi Abloncy, Tamásowi Csíki, Gáborowi Gyáni i Attili Novákowi], „Kommentár” 6/2008, s. 91-104. Por. także nowa odpowiedź Gyániego, tym razem bardziej osobista niż naukowa: Egy magyar holokauszttörténész portréjához [Portret węgierskiego historyka Holokaustu], ibidem, s. 105-112.

${ }^{16}$ Sprawozdanie w: Sz. Panyi, Történészek, ha összejönnek... [Kiedy spotkają się historycy...], „Szombat”, październik 2008, http://www.szombat.org/torteneszek+ha+osszejone k...html.

${ }^{17}$ Worldwide Shoah Memoirs Collection [Ogólnoświatowa Kolekcja Pamiętników Shoah] http://memoirs.claimscon.org

${ }^{18}$ L.O. Vasváry, Lefordított traumák, lefordított életek: holokauszt-túlélö magyar nõk az emigrációban [Przełożona trauma, przełożone życia: węgierscy ocaleni z Holokaustu na emigracji], „Múlt és Jövő” 2009/I, s. 3562. 
wała natomiast obszerną antologię, rozważając w niej specyfikę narracji ocalonych kobiet ${ }^{19}$. W zbiorze poświęconym wydarzeniom 1956 r. (pod redakcją Gyániego) Júlia Vajda zamieściła artykuł o tym, jak ocaleni z Zagłady postrzegali rewolucję roku 1956 (na podstawie wywiadów z ocalonymi ${ }^{20}$ ). Badaczka opublikowała także artykuł poświęcony traumie, którą stanowiła utrata ojca w czasie Szoa ${ }^{21}$. W tym miejscu wspomnieć należy o bazie danych Centropa, utworzonej w Wiedniu, ale mającej aktywnie działającą filię węgierską, którą kierują Eszter Andor i Dora Sar$\mathrm{di}^{22}$. Centropa zgromadziła wypowiedzi 1300 ocalonych z Europy i Turcji. Strona węgierska odsyła głównie do źródeł zebranych przez Narodowy Komitet Wsparcia dla Deportowanych (DEGOB), które mówią o losach niemal 5 tysięcy ocalonych z Węgier w roku $1945^{23}$.

\section{Literatura Szoa i relacje świadków}

Węgierska historiografia wiele zawdzięcza pisarzowi Imre Kertészowi, który w swej powieści z roku 1975 Los utracony zbliżył się do dyskursu historycznego w ukazaniu Szoa. Choć Kertész nie cieszy się w swej ojczyźnie powszechną sympatią, czego dowiodła choćby ostra polemika stoczona w mediach zimą roku 2009, dla wielu badaczy stanowi autorytet, a jego ostatnia książka - zbiór listów - adresowana do niemieckiej krytyki literackiej, ma ogromne znaczenie dla współczesnej tożsamości żydowskiej na Węgrzech, a także dla jego pisarskiego dzieła ${ }^{24}$. „Múlt és Jövő" w roku 2009 poświęcił Kertészowi wiele artykułów autorstwa badaczy węgierskich i zagranicznych, w tym np. Marii Janion ${ }^{25}$. Wydany w 2007 r. „Słownik Kertésza” jest próbą ludycznej analizy w formie wstępu do dyskursu Kertésza na temat Szoa i tożsamości żydowskiej oraz relacji z kulturą węgierską. ${ }^{26}$

Filozof Ottó Szabolcs opublikował ostatnio serię esejów na temat implikacji filozoficznych, moralnych i psychologicznych Szoa. Mimo pewnych nieścisłości histo-

${ }^{19}$ Sós kávé. Elmeséletlen nói történetek, red. K. Pécsi, Budapest 2007. Wyd. ang.: Salty coffee: untold stories by Jewish women.

${ }^{20} \mathrm{~J}$. Vajda, 1956-ahogy azt a soá túléloói elbeszélik [Rewolucja roku 1956 w oczach ocalonych z Szoa] [w:] Ezerkilencszázötvenhat az újabb történeti irodalomban, red. G. Gyáni, J.M. Rainer, Budapest 2007, s. 371-387.

${ }^{21}$ Eadem, „És akkor jött az úgynevezett SAS-behívó”- az apavesztés holokauszt-traumája [„Aż przyszło wezwanie na roboty przymusowe”: trauma holokaustowa po utracie ojca], „Múlt és Jövő” 2009/2, s. 52-64.

22 http://www.centropa.hu i www.centropa.org.

${ }^{23}$ http://www.degob.hu i http://www.degob.org. Angielski przekład tych ważnych stron dostępny od roku 2006.

${ }^{24}$ I. Kertész, Haldimann-levelek [Listy do Haldimann], Budapest 2010.

${ }^{25}$ M. Janion „Ha látszólág egészen másról beszélek, akkor is Auschwitzról beszélek” [O czymkolwiek myślę, zawsze myślę o Auschwitz], „Múlt és Jövő” 2009/I. Por. także nr2009/3, poświęcony Kertészowi.

${ }^{26}$ L.F. Földényi, „Az irodalom gyanúba keveredett”. Kertész Imre-szótár [„Literatura stała się podejrzliwa”. Słownik Imre Kertésza], Budapest 2007. 
rycznych, starał się z pokorą i wrażliwością uchwycić pojęcia związane z doświadczeniem Zagłady (empatia, grzech, żałoba) ${ }^{27}$.

Stale publikuje się wiele pamiętników i relacji o Szoa. Są wśród nich opowieści osób, które były wówczas dziećmi, a relacja Sáriki Székely, ocalonej z Gyergyószentmiklós, jednej z nielicznych na Węgrzech gmin żydowskich, w których posługiwano się językiem jidysz, reprezentuje transylwańskie pamiętniki z życia prostych Żydów i ich tragicznej zagłady ${ }^{28}$.

Na polu badań literackich oraz historii sztuki w 2009 r. opublikowano dwie ciekawe prace. Pierwsza, pod redakcją Eszter B. Gantner i Pétera Réti, przedstawia interesującą refleksję na temat formy uczczenia i zachowania pamięci Szoa, a także stawiania pytań w filmach, sztuce i literaturze ${ }^{29}$. Zaletą tego tomu jest zestawienie dzieł węgierskich z niemieckimi i amerykańskimi (dwa obszerne materiały o Sebaldzie). Może on jednak rozczarować tych, którzy oczekują bardziej bezpośredniej perspektywy porównawczej dla węgierskiej pamięci artystycznej. Druga publikacja, oparta na materiałach międzynarodowych, stanowi filozoficzno-historyczne opracowanie literatury Szoa ${ }^{30}$. Tamás Kisantal wybrał wciąż rzadkie na Węgrzech podejście interdyscyplinarne z pogranicza filozofii, literatury i historii sztuki w dziedzinie interpretacji historycznej form literackich w książkach o Zagładzie z lat 1980-1990. Opierając się na teoriach Berela Langa i Michela Foucaulta, autor podejmuje formalną i historyczną analizę trzech nowatorskich estetycznie utworów: Maus. Opowieść ocalonego Arta Spiegelmana, Biaty hotel Donalda Michaela Thomasa i Árnyas föutca [Cienista ulica] węgierskiego pisarza László Mártona. Kisantal analizuje też książkę Rzeźnia numer pięć Kurta Vonneguta, która nie mówi wprawdzie o Szoa, tylko o bombardowaniu Drezna, ale wykazuje formalną i filozoficzną bliskość z innymi dziełami. Autor podejmuje dyskusyjną kontekstualizację dzieł poprzez ich odniesienie do „kanonu literackiego” Zagłady, który - jego zdaniem - stanowią dzieła Elie Wiesela, Primo Leviego i Tadeusza Borowskiego. Szkoda tylko, że zabrakło tu szerokiej bibliografii oraz indeksu.

Tłumaczenie z francuskiego: Krystyna Szeżyńska-Maćkowiak

${ }^{27}$ O. Szabolcs, Nappalok és éjszakák: tizenegy esszé a holokausztról [Dni i noce. 14 esejów o Holokauście], Budapest 2007.

${ }^{28}$ S. Székely, Szurika, Éva lánya [Szurika, córka Ewy], z wprowadzeniem Dániela Löwy, Budapest 2008.

${ }^{29}$ Az eltünt hiány nyomában. Az emlékezés formái [Śladami minionego. Formy pamięci], red. E.B. Gantner, P. Réti, Budapest 2009

${ }^{30}$ T. Kisantal, Túlélő történetek. Ábrázolásmód és történetiség a holokauszt múvészetében [Opowieści ocalonych. Świat wyobrażeń i historii w sztuce Holokaustu], Budapest 2009. 